\title{
Komposisi, Kelimpahan Dan Keanekaragaman Fitoplankton Di Pulau Salah Nama Sungai Musi Sumatera Selatan
}

\author{
Mirna Dwirastina ${ }^{1 *}$ dan Etti Riani ${ }^{2}$ \\ *e-mail: mirna.rastina@gmail.com \\ ${ }^{1}$ Peneliti Balai Riset Perikanan Perairan Umum dan Penyuluhan Perikanan \\ ${ }^{2}$ Dosen Program Pascasarjana Prodi ManajemenPerikananUniversitas Terbuka
}

\begin{abstract}
Salah Nama Island is also called Banjar Island, located in Banyuasin 1, Mariana Ilir, Musi River, South Sumatra. The area of Salah Nama Island is around 170 ha. Phytoplankton is one of the parameters of aquatic fertility. Algae or phytoplankton can act as one of the ecological parameters that can describe the condition of a water and is an important biotic component in the metabolism of water bodies, because it is the primary chain in the food chain of aquatic ecosystems. The purpose of the study is to provide information about composition, abundance and diversity phytoplankton on Salah Nama Island of South Sumatra. The research was conducted on Salah Nama Island. The name of the sampling point is 5 stations. When the study was conducted in August 2016, November 2016 and January 2017. The results of the study found 3 classes of phytoplankton namely Bacillariophyceae, Chlorophyceae and Cyanophyceae. The highest composition is found in the Bacillariophyceae class. The abundance of phytoplankton ranges from $4.2 \times 103$ cell / 1 to $2.34 \times 105$ cell / 1 . The diversity index of phytoplankton on Salah Nama Island is $0-3$ which is included in category $1<\mathrm{H}^{\prime}<3$, said the stability of the community of moderate biota.
\end{abstract}

Keywords: Composition, Abundance, Diversity, Phytoplankton, Salah Nama Island

\begin{abstract}
ABSTRAK
Pulau Salah Nama disebut juga Pulau Banjar terletak di Kabupaten Banyuasin 1 Kelurahan Mariana Ilir Sungai Musi Sumatera Selatan. Luas Pulau Salah Nama sekitar 170 ha. Fitoplankton merupakan salah satu parameter kesuburan perairan. Alga atau fitoplankton dapat berperan sebagai salah satu parameter ekologi yang dapat menggambarkan kondisi suatu perairan dan merupakan komponen biotic penting dalam metabolisme badan air, karena merupakan mata rantai primer di dalam rantai makanan ekosistem perairan.Tujuan penelitian adalah untuk memberikan informasi tentang komposisi, kelimpahan dan keanekaragaman fitoplankton di Pulau Salah Nama Sumatera Selatan. Penelitian dilakukan di Pulau Salah Nama dengan titik pengambilan sampel ada 5 stasiun. Waktu penelitian dilakukan Agustus 2016, November 2016 dan Januari 2017. Hasil penelitian ditemukan 3 kelas fitoplankton yaitu Bacillariophyceae, Chlorophyceae dan Cyanophyceae. Komposisi

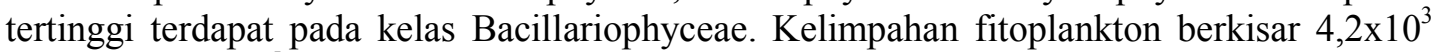

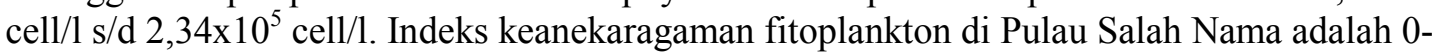
3 yang termasuk dalam kategori $1<\mathrm{H}^{\prime}<3$ dikatakan stabilitas komunitas biota sedang.
\end{abstract}

Kata Kunci: Komposisi, Kelimpahan, Keanekaragaman, Fitoplankton, Pulau Salah Nama

\section{PENDAHULUAN}

Pulau Salah Nama sering disebut juga dengan Pulau Banjar. Pulau ini merupakan daerah perairan Rawa yang dipengaruhi pasang surut. Luas Pulau 
Salah Nama sekitar 170 ha dimana hamper semua masyarakat mempunyai mata pencaharian sebagai nelayan dan bersawah. Pulau ini terletak di Banyuasin 1 Kelurahan Mariana ilir. Sebagaian besar lokasi di tutupi hutan pedado (Sonneratiaacida) serta dibagian yang tidak dimasuki air pasang berupa sawah penduduk. Pada bagian kiri Pulau Salah Nama merupakan areal perlintasan kapal dan sebelah kanan pulau merupakan areal penangkapan ikan dan sebagian kecil terdapat perkampungan penduduk. Pada bagian pinggir Sungai Musi yang berseberangan dengan Pulau Salah Nama banyak terdapat pemukiman penduduk dan beberapa industri antara lain industri minyak goreng dan industri pembuatan kapal.

Salah satu komponen biotik yang menentukan diperairan yaitu plankton. Plankton merupakan organisme yang melayang-layang di perairan. Secara umum plankton dapat dibedakan menjadi dua yaitu fitoplankton yang berupa tumbuhan sedangkan yang berupa hewan sering disebut zooplankton. Fitoplankton merupakan produsen primer diperairan karena memiliki kemampuan untuk melakukan fotosintesis. Menurut Samudra, et al.,(2013) alga atau fitoplankton dapat berperan sebagai salah satu parameter ekologi yang dapat menggambarkan kondisi suatu perairan dan juga merupakan komponen biotik penting dalam metabolisme badan air, karena merupakan mata rantai primer di dalam rantai makanan ekosistem perairan. Perubahan ukuran, jenis dan jumlah populasi plankton di perairan dapat menggambarkan keadaan struktur komunitas perairan (Umar, 2010). Fitoplankton sering dijadikan indikator kesuburan perairan. Informasi tentang fitoplankton sangat penting dalam hal mengetahui kualitas perairan suatu perairan terutama pada perairan yang tidak mengalir atau tergenang.

Pengamatan plankton khususnya fitoplankton merupakan suatu cara pengamatan lingkungan secara biologi yang secara tidak langsung dapat memberikan gambaran tentang keadaan suatu lingkungan perairan.

Penelitian ini bertujuan untuk mengetahui komposisi, kelimpahan dan keanekaragaman fitoplankton di Pulau Salah Nama Sungai Musi Sumatera Selatan.

\section{BAHAN DAN METODE}

Penelitian dilakukan di Pulau Salah Nama disebut juga dengan nama Pulau Banjar (Gambar 1). Penelitian ini telah dilakukan pada bulan Agustus dan November 2016 dan Januari 2017.Penentuan stasiun pengambilan sampel dilakukan dengan metode purposive sampling. Stasiun pengambilan sampel terdiri dari 5 stasiun. Stasiun 1 mewakili daerah pemukiman, stasiun 2 mewakili daerah rawa, stasiun 3 mewakili daerah yang ditumbuhi tanaman air riparian berupa hutan gambut, stasiun 4 mewakili daerah lalu lintas kapal dan stasiun 5 mewakili daerah erosi. 


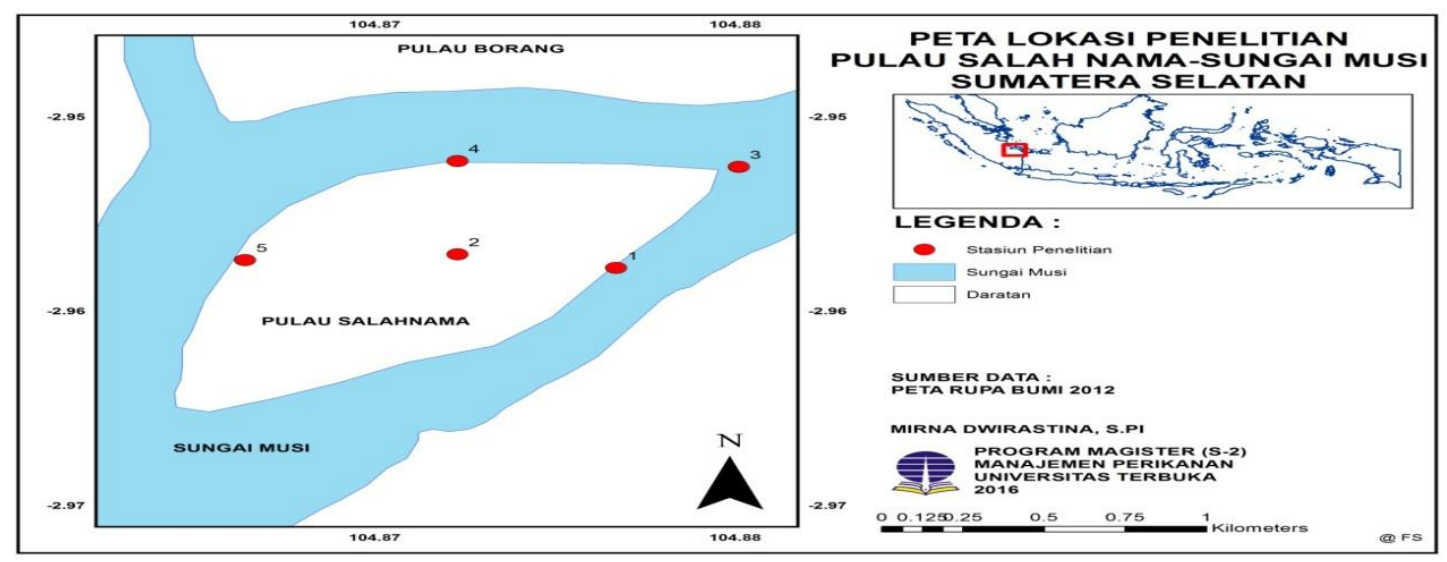

Gambar 1. Lokasi Penelitian di Pulau Salah Nama

Kelimpahan plankton dinyatakan secara kuantitatif dalam jumlah sel/liter dihitung berdasarkan rumus APHA (2005) :

$$
\mathbf{N}=\mathbf{n} \times(\mathbf{v r} / \mathrm{vo}) \times(1 / \mathrm{vs})
$$

Keterangan :

$\mathrm{N}=$ Jumlah sel per liter

$\mathrm{n}=$ Jumlahsel yang diamati

$\mathrm{Vr}=$ Volume sampel $(\mathrm{ml})$

$\mathrm{Vo}=$ Volume air yang diamati (pada $\mathrm{SRC})(\mathrm{ml})$

$\mathrm{Vs}=$ Volume air yang tersaring

Indeks keanekaragaman merujuk Ludwig and Reynolds, 1988:

$$
\mathbf{H}^{\prime}=\sum_{i=1}^{s}-p i \operatorname{Lnpi}
$$

Keterangan:

$\mathrm{H}^{\prime}=$ Indeks keanekaragaman jenis

$\mathrm{S}=$ Banyaknya jenis

$P i=\mathrm{ni} / \mathrm{N}$

$\mathrm{Ni}=$ Jumlah individu enis ke-i

$\mathrm{N}=$ Jumlah total individu

\section{HASIL DAN PEMBAHASAN}

\section{Komposisi dan Kelimpahan Fitoplankton.}

Berdasarkan penelitian yang dilakukan di lokasi penelitian, komposisi genera fitoplankton yang ditemukan dapat dilihat pada Gambar 2. Berdasarkan pengamatan bulan Agustus
2016 didapatkan data komposisi fitoplankton yaitu ada 3 kelas yang ditemukan yaitu Bacilariophyceae, Chlorophyceae dan Cyanophyceae. Dari hasil persentase komposisi bulan Agustus 2016 s/d Januari 2017 maka kelas fitoplankton yang tertinggi yaitu Bacillariophycea $\quad 50 \%$, kemudian Chlorophyceae $48, \quad 28 \quad \% \quad$ dan Cyanophyceae 22,22\% (Gambar 2). Menurut Adjie, et al (2003) menyatakan bacillariophyceae adalah kelompok alga yang secara kualitatif dan kuantitatif banyak di berbagai tipe perairan baik berupa plankon maupun perifiton.Kelas Bacillariophycea merupakan kelas dari fitoplankton yang bersifat kosmopolit, tahan terhadap kondisi ekstrim, mudah beradaptasi dan mempunyai daya reproduksi yang sangat tinggi (Smith, 1950; Sachlan,1980). Selain kelas Bacillariophyceae diikuti kelas Chlorophyceae.Menurut Sulisetijono (2009) alga berperan sebagai produsen yaitu penyusun fitoplankton yang berperan dalam fotosintesis, dan bagian terbesar fitoplankton adalah Chlorophyta (alga hijau). Fauziah, et al (2015) menyatakan Chlorophyta merupakan produsen utama dalam ekosistem perairan karena sebagian besar fitoplankton (bersel satu dan motil) merupakan anggota Chlorophyta yang memiliki pigmen klorofil sehingga efektif untuk melakukan fotosintesis. Sedangkan persentase terendah pada kelas 
Cyanophyceae (Richmond, 2005) menyatakan melimpahnya jumlah phyllum Cyanophyta karena filum ini mampu beradaptasi dengan keadaan yang kurang menguntungkan $\left(\mathrm{CO}_{2}\right.$ rendah, suhu rendah atau terlalu tinggi, dan cahaya kurang). Lebih lanjut tingginya
Cyanophyta disebabkan saat pengambilan sampel dilakukan saat intensitas cahaya matahari belum terlalu tinggi. Menurut Goldman and Horne (1994) pada saat pagi hari Cyanophyta akan mengapung kepermukaan perairan, demikian juga pada saat malam hari.

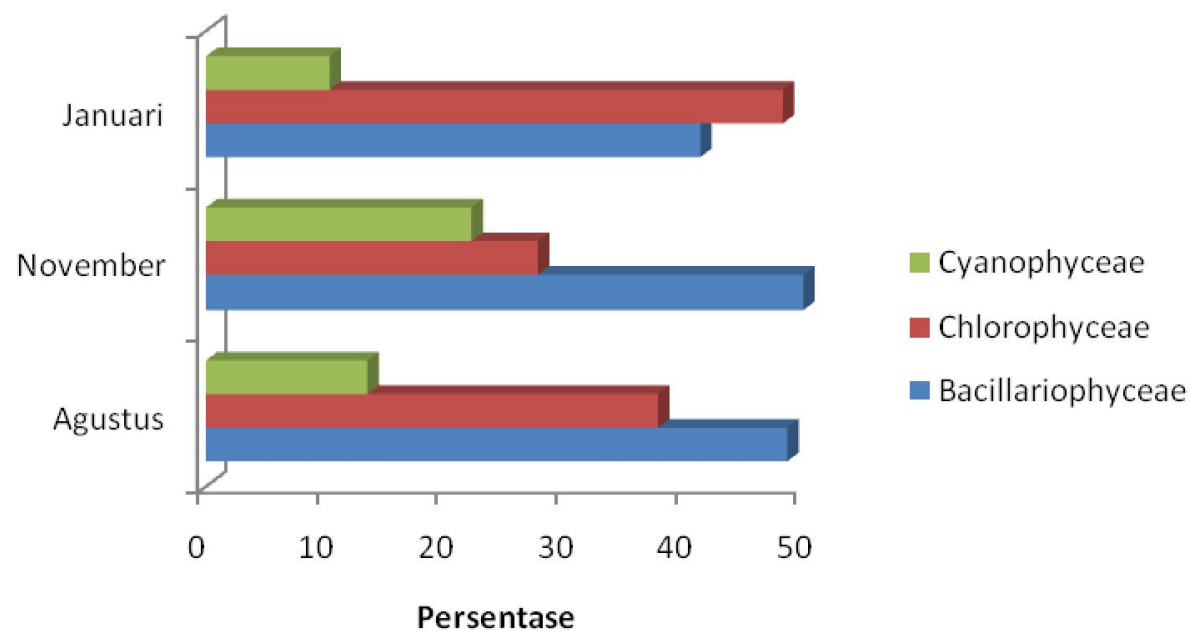

Gambar 2.Komposisifitoplankton di Pulau Salah Nama Agustus 2016 s/d Januari 2017

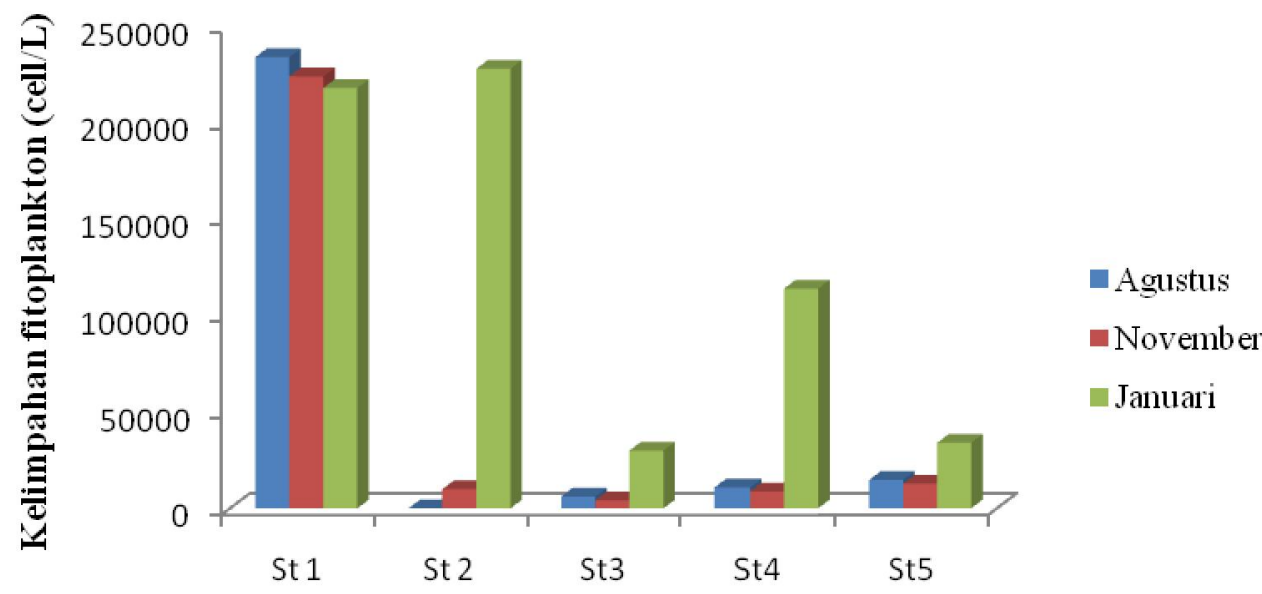

Lokasi

Gambar 3. Kelimpahan Fitoplankton di Pulau Salah Nama Agustus 2016 s/d Januari 2017

Hasil perhitungan kelimpahan fitoplankton tertinggi pada bulan Agustus s/d Januari 2017 tedapat pada stasiun 1 (Gambar 3). Kelimpahan fitoplankon berkisar $4,2 \times 10^{3}$ cell/L s/d $2,34 \times 10^{5}$ cell/L. Pada saat pengambilan sampel bulan Agustus kondisi musim kemarau sehingga kemungkinan yang mempengaruhi kelimpahan fitoplankton tersebut karena faktor sehingga air sedikit surut dan arusnya sangat kecil menyebabkan kelimpahan fitoplankton yang didapat melimpah. Disamping itu stasiun 1 merupakan daerah yang 
mewakili pemukiman, tetapi daerah ini banyak ditumbuhi tanaman air riparian sehingga memungkinkan fitoplankton banyak. Gambar 3 menunjukkan bahwa stasiun 1 kelimpahan fitoplankton melimpah baik bulan Agustus, November dan Januari. Hal ini dikarenakan stasiun 1 merupakan daerah yang mewakili pemukiman dan merupakan daerah saluran masukknya air sungai menuju rawa banjiran. Pada musim kemarau stasiun 1 tidak mengalami kekeringan karena stasiun ini dipengaruhi aliran DAS sungai Musi sehingga senantiasa selalu berisi air. Arus yang terjadi tidak terlalu deras sehingga hal ini memungkinkan fitoplankton banyak terdapat disini dan didukung dengan kondisi tanaman air rawa yang masih banyak. Pada stasiun 2 bulan Agustus daerah tersebut kering sehingga sampel air tidak bisa diambil, tetapi bulan Januari mengalami peningkatan ketinggian air, sehingga air masuk kerawa dan daerah rawa banjiran di Pulau Salah Nama terendam air, hal ini kemungkinan menyebabkan fitoplankton banyak dilokasi tersebut.

Whitton (1975) diacu oleh Faza (2012) menyatakan bahwa pada perairan yang berarus $0,5-1 \mathrm{~m} / \mathrm{s}$ kelas plankton yang mendominasi adalah kelas dari diatom (Bacillariophyceae). Keberadaan plankton di perairan mengalir dipengaruhi oleh lingkungan sungai yang seringkali komposisinya berubah yang berkaitan dengan pergerakan air, kekeruhan, suhu, dan nutrien (Hynes, 1972). Perkembangan komunitas fitoplankton sungai dipengaruhi oleh turbulensi aliran dan turbiditas yang berkaitan dengan partikel tersuspensi (Belcher dan Swale 1979 in Reynolds 1984). Welch (1952) mengungkapkan bahwa beberapa faktor yang mempengaruhi distribusi kelimpahan fitoplankton dalam suatu perairan adalah arus, kandungan unsur hara, predator, suhu, kecerahan, kekeruhan, $\mathrm{pH}$, gas-gas terlarut, maupun kompetitor. Hunter (1970) in Basmi (1988) juga mengungkapkan bahwa melimpahnya fitoplankton di suatu perairan berkaitan dengan pemanfaatan unsur hara dan radiasi sinar matahari. Selain itu, suhu, lingkungan, dan pemangsaan oleh zooplankton juga ikut berperan. Besar kecilnya konsentrasi nutrien sangat ditentukan oleh kondisi lingkungan itu sendiri maupun masukan dari luar.

Nilai indeks keanekaragaman fitoplankton bulan Agustus, November 2016 s/d Januari 2017 dapat dilihat pada Tabel 1. Berdasarkan nilai indeks keanekaragaman $\left(\mathrm{H}^{\prime}\right)$ fitoplankton yang ada di Pulau Salah Nama berkisar 0-3. Indeks keanekaragaman (H') digunakan untuk mengetahui kenekaragaman jenis biota di perairan. Kriteria tingkat pencemaran berdasarkan indeks keanekaragaman $\left(\mathrm{H}^{\prime}\right)$ adalah $\mathrm{H}^{\prime}<1$ berarti komunitas biota tidak stabil atau jika nilai tersebut $1<\mathrm{H}^{\prime}<3$ dikatakan stabilitas komunitas biota sedang atau dan $\mathrm{H}^{\prime}<3$ maka stabilitas komunitas biota dalam kondisi stabil (Fachrull, 2007). Nilai indeks keanekaragaman fitoplankton tertinggi terdapat pada stasiun 2. Stasiun 2 merupakan stasiun yang mewakili daerah rawa banjiran yang banyak ditumbuhi oleh tanaman air dan pada musim kemarau lokasi akan kering karena air sangat surut. Nilai $\mathrm{H}^{\prime}$ fitoplankton di Pulau Salah Nama dikategorikan $\quad 1<\mathrm{H}^{\prime}<3 \quad$ dikatakan stabilitas komunitas biota fitoplankton masih sedang.

Tabel 1. Nilai Indeks Keanekaragaman fitoplankton di Pulau Salah Nama

\begin{tabular}{cccccc}
\hline Indeks & St 1 & St 2 & St3 & St4 & St5 \\
\hline $\begin{array}{c}\text { Kenakeragaman } \\
\left(\mathrm{H}^{\prime}\right)\end{array}$ & $1,36-1,79$ & $1,42-2,18$ & $1,17-1,87$ & $1,40-1,82$ & $0,41-1,6$ \\
\hline
\end{tabular}




\section{KESIMPULAN}

Berdasarkan penelitian yang telah dilakukan maka hasil identifikasi fitoplankton ditemukan 3 kelas yaitu Bacillariophyceae, Chlorophyceae dan Cyanophyceae. Kelimpahan fitoplankon berkisar $4,2 \times 10^{3}$ cell/1 $\mathrm{s} / \mathrm{d} 2,34 \times 10^{5}$ cell/1 dan nilai indeks keanekaragaman berkisar $1<\mathrm{H}<3$, nilai ini menandakan kondisi perairan dalam kategori sedang.

\section{Ucapan Terima Kasih (jika diperlukan)}

Penulis dapat menambahkan ucapan terimakasih kepada pihak-pihak yang telah membantu pelaksanaan penelitian.

\section{DAFTAR PUSTAKA}

Daftar pustaka disusun berdasarkan urutan abjad tanpa nomor urut dengan kelengkapan: nama pengarang, tahun penerbitan, judul artikel, judul buku, nama dan nomor jurnal, penerbit dan kota tempat diterbitkan, serta jumlah halaman/nomor halaman atau mengacu pada format sitasi APA (American Psychological Association) 6th edition. Penulis sangat disarankan untuk menggunakan manajer referensi seperti Mendeley, Endnote, Zotero, atau yang sudah terinstal plugin di Ms Word untuk memudahkan penulis dan mengurangi kesalahan sitasi. Jika ada, DOI artikel hendaknya ditampilkan.

\section{Jurnal Ilmiah:}

Alfarisa, S., Abu Bakar, S., Mohamed, A., Hashim, N., Kamari, A., Md Isa, I., ... Rusop Mahmood, M. (2015). Carbon Nanostructures Production from Waste Materials: A Review. Advanced Materials Research, 1109, 25-29. https://doi.org/10.4028/www.scient ific.net/AMR.1109.25
Alfarisa, S., Dwandaru, W. S. B., \& Darmawan, D. (2016). Density Profiles, Energy, and Oscillation Strength of a Quantum Dot in Two Dimensions with a Harmonic Oscillator External Potential using an Orbital-free Energy Functional Based on Thomas-Fermi Theory. Makara Journal of Science, 20(1), 38

https://doi.org/10.7454/mss.v20i1.5 $\underline{658}$

\section{Prosiding:}

Aji, S. D., Hudha, M. N., Huda, C., Khoiro, Z., Wartono, W., Batlolona, J. R., ... \& Abdullah, A. G. (2018). Adaptive multimedia with android e-assessment to improve assessment efficiency. In IOP Conference Series: Materials Science and Engineering (Vol. 434, No. 1, p. 012294). IOP Publishing.

Siahaan, S. M. (2012). Penggunaan Teknologi Informasi dan Komunikasi dalam Pembelajaran Fisika. In Prosiding Seminar Nasional Fisika Universitas Sriwijaya, 4 Juli 2012.(Energi, Lingkungan, dan Teknologi Masa Depan: Tantangan dan Peluang Ilmu Fisika) (pp. 13-20). PT. Mitra Intimarga.

\section{Buku:}

Swara, P., \& Umar, E. (2008). Buku Pintar Fisika. Puspa Swara.

Laszlo, E. (2007). Science and the Akashic field: An integral theory of everything. Simon and Schuster.

Strunk, W., Jr., \& White, E. B. (1979). The elements of style (3rd ed.). New York: Macmillan. 


\section{Halaman Web:}

Shackelford, W. (2000). The six stages of cultural competence. In Diversity central: Learning. Retrieved April 16, 2000, from http://www.diversityhotwire.com/le arning/cultural_insights.html

\section{Skripsi, tesis, disertasi:}

Biswas, S. (2008). Dopamine D3 receptor: $A$ neuroprotective treatment target in Parkinson's disease. Retrieved from ProQuest Digital Dissertations. (AAT 3295214)

Adams, R. J. (1973). Building a foundation for evaluation of instruction in higher education and continuing education (Doctoral dissertation). Retrieved from http://www.ohiolink.edu/etd/ 